\title{
Parasites of Small Mammals in Grand Teton NATIONAL PARK: BABESIA AND HePatozoon
}

\author{
RAYCHEL A. WATKINS $\downarrow$ SUZANNE E. MOSHIER \\ DEPARTMENT OF BIOLOGY $\downarrow$ UNIVERSITY OF NEBRASKA AT OMAHA
}

AND

\section{AELITA J. PINTER $\downarrow$ DEPARTMENT OF BIOLOGICAL SCIENCES UNIVERSITY OF NEW ORLEANS $\uparrow$ LA}

\section{$\downarrow \quad$ INTRODUCTION}

Babesia microti, a parasitic protozoan, is endemic in the Microtus montanus of Grand Teton National Park. It is transmitted by the tick Ixodes eastoni and reproduces in the erythrocytes of its vole host.

A second protozoan parasite, Hepatozoon sp., which is widespread in small mammals in Europe, is also found in reptiles throughout the world. The record of Hepatozoon in North American small mammals is not extensive.

Hepatozoon, unlike Babesia, may be a two-host or a three-host parasite. Also unlike Babesia, for which the intermediate host is always a tick, the intermediate host of Hepatozoon may be a tick, a mite, a flea, or a mosquito. The method of transmission by the vector also differs in the two parasites. Babesia is transmitted in the tick's saliva when it bites, whereas Hepatozoon infection requires the vertebrate host to ingest a vector.

In our 1996 studies, we sought more data on these two parasites. The objectives for 1996 focused on Hepatozoon: to sample specific populations of $M$. montanus, in which we have previously documented Hepatozoon infections; to determine whether differences exist in the infection rates at different study sites in the park; and to search for any additional vectors of Hepatozoon sp. infections in $M$. montanus by examining ectoparasites. These studies contributed to our long-term objectives of documenting the effects and cost of parasitism on $M$. montanus populations.

\section{$\downarrow$ METHODS}

All animals were trapped at sites within the boundaries of Grand Teton National Park using Sherman live-traps. The permit to collect small mammals in Grand Teton National Park was granted to A. J. Pinter. Upon removal from the traps, voles were killed by overanesthesia, then a 25 gauge needle was inserted into the left ventricle of the heart, and blood was collected in a heparinized tuberculin syringe. The blood was transferred to a micro-centrifuge tube. Several slides of peripheral blood smears were made from this blood. Slides were fixed in methanol and stained with Wrights-Giemsa stain. The peripheral blood smears were examined for the presence of Babesia, Hepatozoon, and other parasites.

The spleen, liver, and lungs were removed. Impression and squash smears of the organs were 
made and examined for the presence of parasites, especially for the schizonts of Hepatozoon, with a light microscope equipped with $15 \mathrm{X}$ oculars and a $100 \mathrm{X}$ oil objective.

Fleas were collected from the live-trapped animals, both before and after overanesthesia, whenever they were detected. They were either squashed and examined with a light microscope for the presence of oocysts, or they were placed in $70 \%$ ethanol and later sent for identification to Dr. Robert E. Lewis at Iowa State University.

\section{$\downarrow$ RESUlTS AND DISCUSSION}

Table 1 shows the results of trapping for 1988 through 1996. The extremes of infection rate for Babesia microti occurred in 1996 when there was a low of $16.7 \%$ in the spring and in 1995 when the high of $100 \%$ was recorded in the spring. Except for 1996, the spring rate of infection was always higher than that of the summer. This finding is consistent with Lxodes eastoni's being a nest tick (personal communication, Richard G. Robbins) and $M$. montanus' living in the same nest until spring, with no dispersal occurring until the onset of the spring snowmelt and the breeding season.

\begin{tabular}{|c|c|c|c|c|c|c|}
\hline \multirow{2}{*}{$\begin{array}{l}\text { Year } \\
1996\end{array}$} & \multirow{2}{*}{$\begin{array}{l}\text { Season } \\
\text { Spring }\end{array}$} & \multirow{2}{*}{$\begin{array}{c}\begin{array}{c}\text { Number } \\
\text { caught }\end{array} \\
18\end{array}$} & \multicolumn{2}{|c|}{$\begin{array}{l}\text { Number positive } \\
\text { Babesia Hepatozoon }\end{array}$} & \multicolumn{2}{|c|}{$\begin{array}{c}\text { Per cent positive } \\
\text { Babesia Hepatozoon }\end{array}$} \\
\hline & & & 3 & 3 & 16.7 & 16.7 \\
\hline & Summer & 19 & 14 & 0 & 73.7 & 0 \\
\hline \multirow[t]{2}{*}{1995} & Spring & 19 & 19 & 0 & 100.0 & 0 \\
\hline & Summer & 31 & 13 & 0 & 41.9 & 0 \\
\hline \multirow[t]{2}{*}{1994} & Spring & 9 & 5 & 0 & 55.6 & 0 \\
\hline & Summer & 59 & 27 & 0 & 45.8 & 0 \\
\hline \multirow[t]{2}{*}{1991} & Spring & 23 & 17 & 4 & 73.9 & 17.4 \\
\hline & Summer & 74 & 19 & 5 & 25.7 & 6.8 \\
\hline \multirow[t]{2}{*}{1990} & Spring & 16 & 9 & 0 & 56.3 & 0 \\
\hline & Summer & 58 & 19 & 5 & 32.8 & 8.6 \\
\hline \multirow[t]{2}{*}{1989} & Spring & 35 & 16 & 12 & 45.7 & 34.3 \\
\hline & Summer & 34 & 13 & 1 & 38.2 & 2.9 \\
\hline \multirow[t]{2}{*}{1988} & Spring & 20 & 13 & 0 & 65.0 & 0 \\
\hline & Summer & 53 & 16 & 9 & 30.2 & 17.0 \\
\hline
\end{tabular}

Samples of Babesia-infected blood were given to Yolanda Peck, a biology graduate student at the University of Nebraska at Omaha, for work-up and subsequent sequence analysis of the 16S-like rRNA gene of the parasite. Working with the guidance of Dr. Bruce Chase, Biology Department, University of Nebraska at Omaha, she sequenced the gene, and analysis of the results is in progress (personal communication, Dr. Bruce Chase; Peck and Chase, 1997).

Originally, Babesia was thought to be restricted to small mammals; however, in 1970 the first human cases were diagnosed in residents of Nantucket Island, Massachusetts (Western et al, 1970). In the United States, human babesiosis is caused primarily by $B$. microti but also by a recently recognized, as yet unspeciated, organism designated WA-1 (Thomford et al., 1994). As humans insert themselves into places where they have historically been present little, they sometimes contract new diseases, and the proximity of humans to ticks in Grand Teton National Park suggests that the status of babesiosis in small mammals of the park should be monitored.

Hepatozoon sp. is the other endoparasite of M. montanus that we continued to study in 1996 . The infection rates for 1996 and previous collection years are displayed in Table 1. Rates of infection of M. montanus with Hepatozoon are characteristically lower than with B. microti; in 1994 and 1995 we found no Hepatozoon infections at all in either the spring or the summer.

Hepatozoon sp. infections have been found in M. montanus from 8 study sites. Since some sites appeared to have a higher infection rate than other sites, one of the goals for 1996 was to determine whether this observation could be more thoroughly documented with more data. Unfortunately, for the third consecutive year we found too few animals infected with Hepatozoon to accomplish this goal.

Since the inception of our studies, we have photographed as many stages in the life cycle of Hepatozoon as possible. This year we report the discovery in $M$. montanus of monozoic and dizoic cysts, two little known features of the life cycle of Hepatozoon. First described in reptiles by Landau et al.in 1972 (Desser, 1990), these cysts are latent forms that are infective when the host in ingested by a predator. Thus, they constitute a second mode of transmission to a vertebrate besides the better known route by ingestion of an infected invertebrate. Microtus montanus may harbor monozoic cysts, dizoic cysts, and schizonts. Figures 1-3 show dizoic 
cysts; Figure 4 shows a monozoic cyst. For comparison, Figures 7 and 8 show several merozoites from a ruptured schizont. They are not as slender as merozoites previously encountered. We do not know whether this difference reflects their developmental stage, the length of time free from the schizont, species differences, or some other factor. Figures 5 and 6 show vermicules from a preparation in which their motility was observed prior to fixation and staining. They, too, are less slender than vermicules observed previously.

From 1989 through 1995, five flea species, collected as intact specimens from $M$. montanus, were identified by Dr. Robert Lewis: Megabothris abantis, Me. asio megacolpus, Aetheca wagneri, Peromyscopsylla selenis and Hystrichopsylla dippiei dippiei. He also identified one of the two host fleas as Me. abantis. In 1996 a sixth species, Peromyscopsylla hesperomys, was collected from 2 different voles and identified by Dr. Lewis.

We presented many of our recent findings at the annual meeting of the American Society of Parasitologists in June, 1997, in Nashville, Tennessee. The title of our paper was "Hepatozoon sp. Infections in Three Newly Recognized North American Mammalian Hosts (Microtus montanus, Mi. pennsylvanicus, Thomomys talpoides) and the flea Megabothris abantis Identified as an Invertebrate Host in Mi. montanus Infections."

\section{$\downarrow$ ACKNOWLEDGMENTS}

We are grateful to Dr. Robert E. Lewis, Department of Entomology, Iowa State University, for identifying fleas. Thanks to Elisabeth Miller for able assistance in both the field and the laboratory. We are grateful for the use of the University of Wyoming-National Park Service Research Center facilities, where field work was conducted.

\section{$\downarrow$ LITERATURE CITED}

Desser, S. S. 1990. Tissue "Cysts" of Hepatozoon griseisciuri in the Grey Squirrel, Sciurus carolinensis: The Significance of These Cysts in Species of Hepatozoon. Journal of Parasitology 76: 257-259.
Peck, Y. and B. A. Chase. 1997. The Phylogenetic Characterization of Babesia microti in Grand Teton National Park. Proceedings of the Nebraska Academy of Sciences (Abstract).

Thomford, J. W., P. Conrad, S. R. Telford III, D. Mathiesen, B. H. Bowman, A. Spielman, M. L. Eberhard, B. L. Herwaldt, R. E. Quick, and D. Persing. 1994. Cultivation and phylogenetic characterization of a newly recognized human pathogenic protozoan. Journal of Infectious Diseases 169: 1050-1056.

Western, K. A., G. D. Benson, N. N. Gleason, G. R. Healy, and M. G. Schulz. 1970. Human babesiosis in Massachusetts: First case in a patient with a spleen. New England Journal of Medicine 283: 854-856.

Publications Resulting from Our Investigations at the National Park Service-University of Wyoming Research Center

Peck, Y. and B. A. Chase. 1997. The Phylogenetic Characterization of Babesia microti in Grand Teton National Park. Proceedings of the Nebraska Academy of Sciences.

Watkins, R. A., W. D. O'Dell, S. E. Moshier, and A. J. Pinter. 1992. Hepatozoon sp. Infections Found in Three Newly Recognized North American Mammalian Hosts: Microtus montanus, Microtus pennsylvanicus, and Thomomys talpoides. Proceedings of the Nebraska Academy of Sciences, p. 44.

Watkins, R. A., S. E. Moshier, W. D. O'Dell, and A. J. Pinter. 1991. Splenomegaly and Reticulocytosis Caused by Babesia microti Infections in Natural Populations of the Montane Vole, Microtus montanus. Journal of Protozoology 38: 573-576. 
Watkins, R. A., W. D. O'Dell, and A. J. Pinter. 1989. Redescription of flagellar arrangement in the duck intestinal flagellate, Cochlosoma anatis and description of a new species, Cochlosoma soricis n. sp. from shrews. Journal of Protozoology 36:573-576.

Watkins, R. A., W. D. O'Dell, S. E. Moshier, and A. J. Pinter. 1989. Babesiosis in the Montane Vole, Microtus montanus. Proceedings of the Nebraska Academy of Sciences, p. 31.
Pinter, A. J., W. D. O'Dell, and R. A. Watkins. 1988. Intestinal parasites of small mammals from Grand Teton National Park. Journal of Parasitology 74(1): 187-188. 

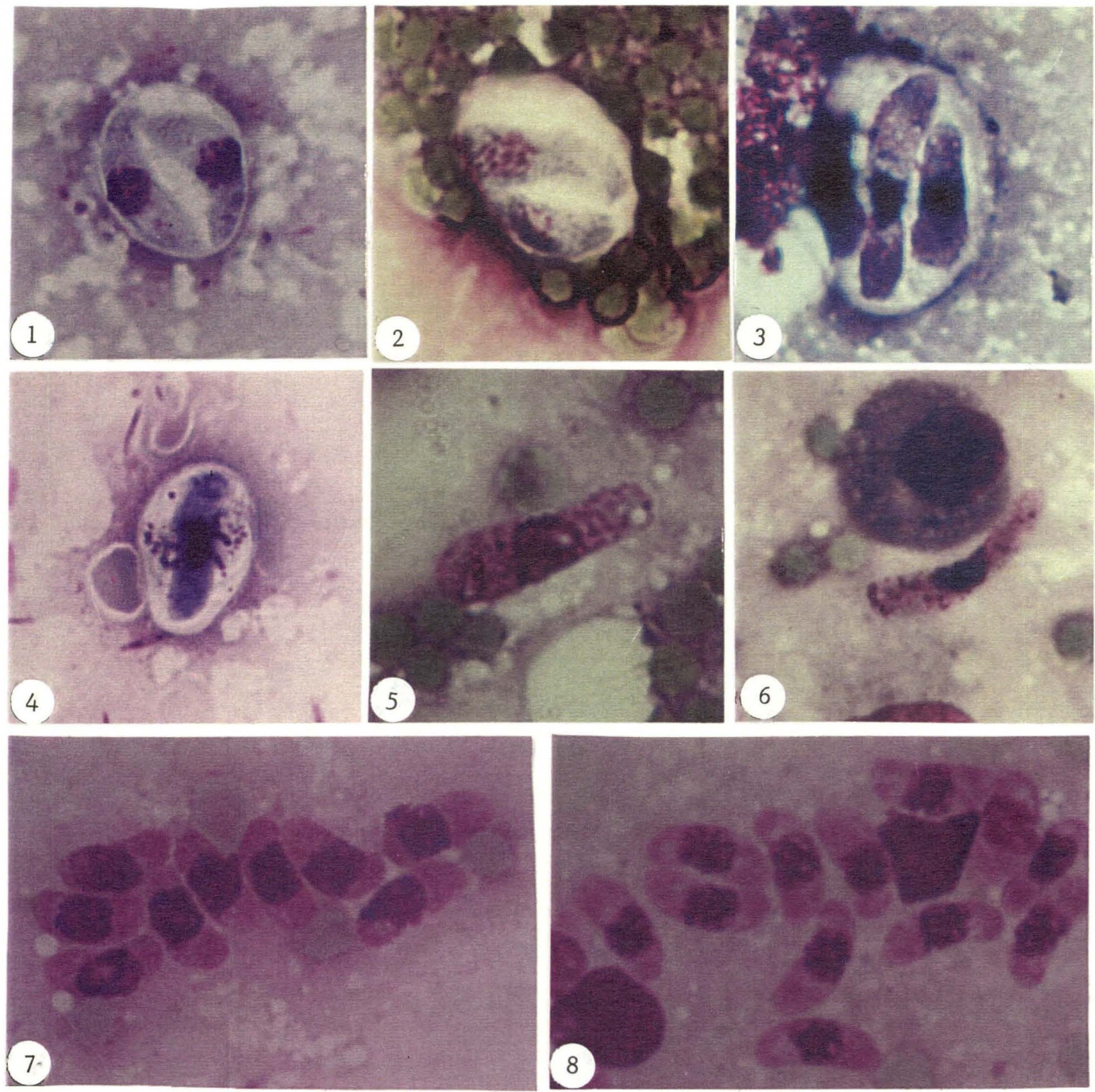

Figures 1-3. Dizoic cysts in lung squashes. Figure 4. Monozoic cyst from a lung squash. Figures 5-6. Vermicules from lung squashes. Figures 7-8. Merozoites from a ruptured schizont in a lung squash. All preparations were stained with Wrights-Giemsa stain. X 1,600. 